Journal of Engineering Sciences, Assiut University, Vol. 40, No 5. pp.1309-1324, September 2012.

\title{
BEHAVIOR OF REPAIRED R.C. BEAMS BY USING STEEL FIBER CONCRETE JACKET AND SUBJECTED TO SHORT TIME REPEATED LOADING
}

\section{Prof. Dr. Yehia. A. Hassanean ${ }^{1} \quad$ Dr. Kamal Abas Assaf ${ }^{\prime}$}

\section{Dr. Shehata E. Abdel Raheem ${ }^{1} \quad$ Eng. Ahmed. N. M. Arafa ${ }^{2}$}

${ }^{1}$ Civil Engineering Department, Assuit University Assuit, Egypt

${ }^{2}$ Civil Engineering Department, Sohage University, Sohage, Egypt

Email: 'kamal_assaf2000@yahoo.com or 2Eng_ahmednour1@yahoo.com

(Received May 23, 2012 Accepted June 4, 2012)

\begin{abstract}
Repairing of reinforced concrete beams by using thin fibers concrete jacket have many advantages such as increasing of ultimate load, enhancement of serviceability limit state, resistance to fire and avoiding of corrosion problems that appear in steel plate jacket. This paper reports investigations conducted to study the repairing of reinforced concrete beams subjected to short time repeated loading by using mixed steel fibers concrete jacket (MSFCJ). For this purpose, eight reinforced concrete beams have $120 \times 300 \times 2300 \mathrm{~mm}$ dimensions were fabricated and tested under three point load. The used concrete mix contains two mixed shape of steel fibers, corrugated and endhooked steel fibers.

Two of these beams were fabricated without jacket, the first was tested under static load up to failure and the second was tested under short time repeated loads up to failure. The rest six beams were loaded up to 0.5 the ultimate static load and then repaired by U-shape jacket (MSFCJ) with various thickness and steel fibers content. The test results showed the effectiveness of the proposed technique in the behavior of such beams.
\end{abstract}

Keywords: Fiber concrete jacket, high-strength concrete, mixed steel fiber, short time repeated loading.

\section{NOTATION}

$\mathrm{V}_{\mathrm{f}}=$ fiber content

$\mathrm{t}_{\mathrm{jb}}=$ jacket thickness at the bottom of the beam in $\mathrm{mm}$

$\mathrm{t}_{\mathrm{js}}=$ jacket thickness at each side of the beam in $\mathrm{mm}$

$\mathrm{F}_{\mathrm{cu}}=$ cube compressive strength in $\mathrm{N} / \mathrm{mm}^{2}$

$\mathrm{F}_{\mathrm{ct}}=$ cylinder splitting tensile strength in $\mathrm{N} / \mathrm{mm}^{2}$

$\mathrm{F}_{\mathrm{cr}}=$ concrete flexural strength in $\mathrm{N} / \mathrm{mm}^{2}$

$\mathrm{P}_{\mathrm{cr}}=$ cracking load in $\mathrm{KN}$

$\delta_{\mathrm{cr}}=$ deflection at cracking load in $\mathrm{mm}$

$\delta_{\mathrm{u}}=$ deflection at ultimate load in $\mathrm{mm}$

$\varepsilon_{\mathrm{su}}=$ main steel strain at ultimate load

$\varepsilon_{\mathrm{cu}}=$ concrete strain at ultimate load

$\mathrm{N}=$ number of cycles 


\section{INTRODUCTION}

The interest of repairing of reinforced concrete structures has increased in the last few years because of poor performance under service loading in the form of excessive deflections and cracking, construction faults, design faults, excessive deterioration and the changing in use of structure. In such circumstances, there are various methods for repairing of R.C beams such as externally bonded steel plates, R.C jacketing and externally bonded fiber reinforced polymer (FRP). All these techniques can be successfully used but have some limits. In particular, the use of RC jacket is possible by adding layers of concrete with thickness larger than $60-70 \mathrm{~mm}$ due to the presence of rebars that require a minimum concrete cover [1]. The use of externally glued steel plates as well as of FRP may have problems for fire resistance. Furthermore, the use of these techniques may not satisfy the minimum requirements for serviceability limit states.

During the last 10 years, the use of concrete reinforced with fibers has increased due to its enhanced flexural, tensile, compressive and fatigue properties. Recently, a new technique has been developed for repairing beams under static loading [2]. This solution is based on the application of a thin jacket in high performance fiber reinforced concrete (HPFRC) with a high compressive strength and a hardening behavior in tension. This method has more advantages such increasing of ultimate load, enhancement of serviceability limit state, resistance to fire and avoiding of corrosion problems that appear in steel plate jacket. This technique in repairing was undertaken to be the main object of this work by using high strength concrete with steel fiber. Also, all previous investigations conducted on SFC, single shape of fibers have been used $[3,4,5]$ and there is no information available on performance of SFC containing fibers of mixed shape. Therefore, the present work was used mixed shape of steel fibers (end hooked, corrugated) with the understanding that the end hooked fibers are effective in increasing the ductility whereas, corrugated fibers are effective in increasing the bond between the components of concrete.

Fatigue strength data of concrete and other materials that are used in structures subjected to repeated loading for obtaining their safe, effective and economical design are needed. A low cycle fatigue is important for structures subjected to earthquake loads. Previous investigations of the fatigue characteristics of reinforced concrete beams have been almost exclusively concerned with the RC beams subjected to long time repeated load. The current knowledge of R.C beams subjected to short time repeated load is extremely limited. Since R.C beams subjected to short time repeated load were undertaken in this work to be the model of beams repaired with mixed steel fiber concrete jacket (MSFCJ).

This work was undertaken to present the repairing of R.C beams subjected to short time repeated loading by using mixed steel fiber concrete jacket and aimed to the following objectives:

1) Study the effect of steel fiber content.

2) Study the effect of the jacket thickness.

3) Study the effect of interface strength. 


\section{EXPEREMINTAL PROGRAM}

\subsection{Details of The Tested Beams}

Eight reinforced concrete beams with a cross section $120 \times 300 \mathrm{~mm}$ and total length of $2300 \mathrm{~mm}$ were fabricated and tested under three point flexural test. The design of the flexural and shear steel reinforcement ensured a flexural failure of the beams. The dimensions and details of reinforcement of the tested beams before the application of the proposed repairing technique are shown in Fig. 1. Also, the properties of the tested beams are given in Table.1.

Two beams $\left(\mathrm{B}_{\mathrm{s}}\right.$ and $\left.\mathrm{B}_{\mathrm{r}}\right)$ without jacket; $\mathrm{B}_{\mathrm{s}}$ was subjected to a static loading up to failure. $\mathrm{B} \mathrm{O}_{\mathrm{r}}$ was subjected to a short time repeated loading up to failure. The maximum level of repeated loading was $95 \%$ of the ultimate static load of beam B $0_{\mathrm{s}}$

The other six beams were loaded up to 0.5 of the ultimate static load of beam B0 $(50$ $\mathrm{KN}$ ). Eventually, the beams repaired using U-shape of MSFC jacket and tested under short time repeated loading.

To study the effect of steel fiber content added to the concrete of jacket on the flexural behavior of repaired beams, three specimens $\mathrm{BRC}_{1}, \mathrm{BRC}_{2}$ and $\mathrm{BRC}_{3}$ were fabricated. These beams were repaired by U-shape MSFC jacket with $40 \mathrm{~mm}$ thickness at the tension surface and $30 \mathrm{~mm}$ at each side but with variable fiber content $1 \%, 1.5$ $\%$ and $2 \%$ respectively. Debonding preventive technique was applied on these beams i.e. the jacket was connected with the main beams by using shear connectors and epoxy adhesive.

To study the effect of the jacket thickness on the flexural behavior of repaired beams, three specimens $\mathrm{BRD}_{1}, \mathrm{BRD}_{2}$ and $\mathrm{BRD}_{3}$ were fabricated. These beams were repaired by U-shape MSFC jacket with $1.5 \%$ fiber content and $30 \mathrm{~mm}$ thickness at each side but with variable thickness at the tension surface $30 \mathrm{~mm}, 40 \mathrm{~mm}$ and $50 \mathrm{~mm}$ respectively. The jacket for all beams was connected to the main beam same as group "C" except $\mathrm{BRD}_{2}$ was without shear connectors to study the effect of interface strength.

The details of the tested beams after the application of the proposed technique are shown in Fig. 2.

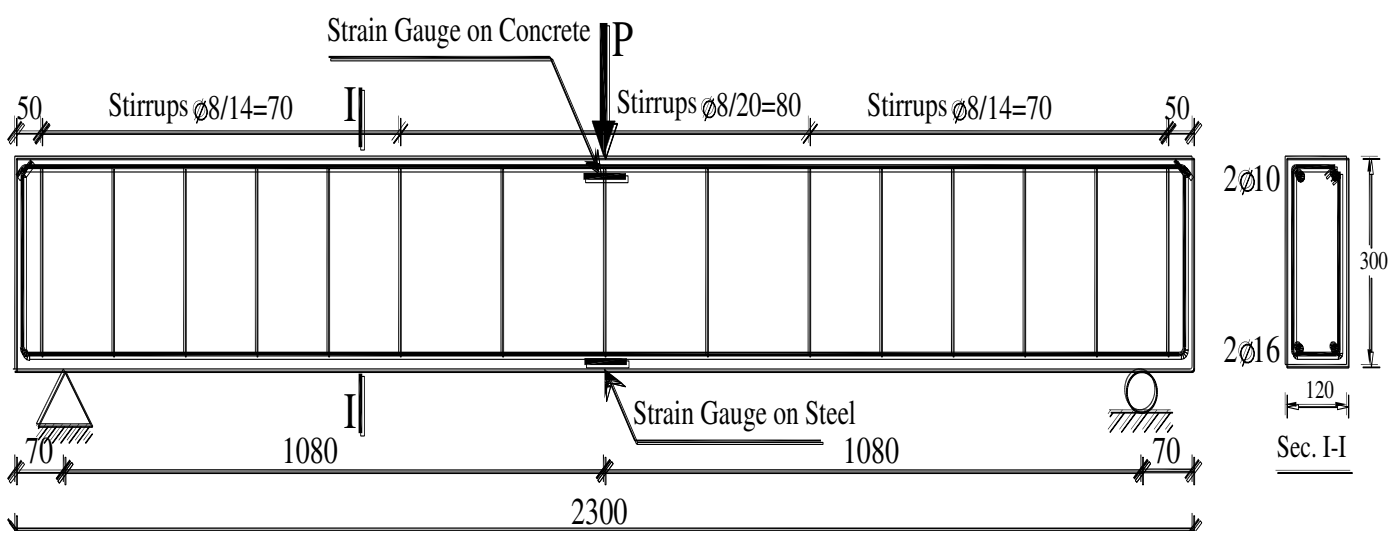

Fig. 1: Details of the tested beams 


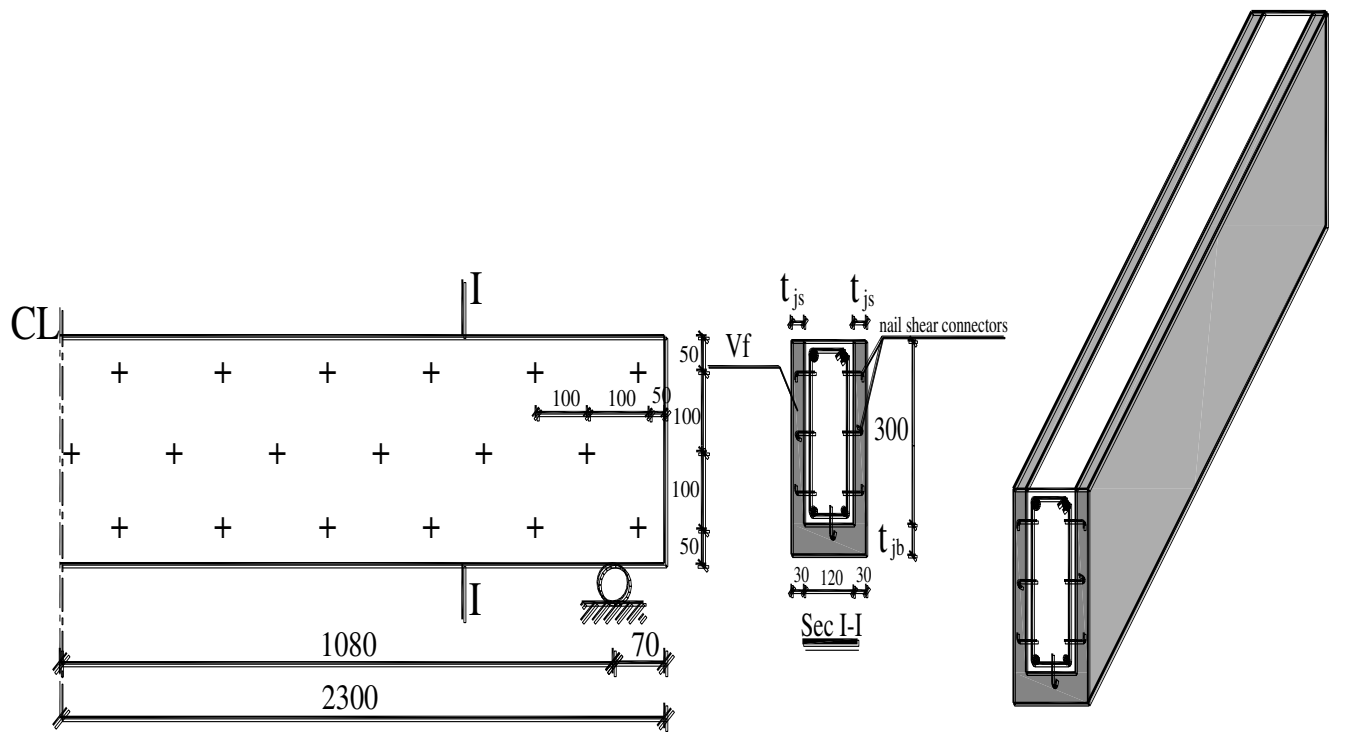

Fig. 2: Repairing scheme and details of shear connectors for all repaired beams except $\mathrm{BRD}_{2}$ without shear connectors.

Table 1: Properties of the tested beams

\begin{tabular}{|c|c|c|c|c|c||}
\hline \multirow{2}{*}{$\begin{array}{c}\text { Beam } \\
\text { No. }\end{array}$} & \multirow{2}{*}{$\mathbf{V}_{\mathbf{f}} \%$} & \multicolumn{2}{|c|}{ Jacket Thickness $(\mathbf{m m})$} & $\begin{array}{c}\text { Shear } \\
\text { Connectors }\end{array}$ & $\begin{array}{c}\text { Loading } \\
\text { Type }\end{array}$ \\
\cline { 3 - 4 } & $\mathbf{t}_{\mathbf{j b}}$ & $\mathbf{t}_{\mathbf{j s}}$ & -------- & Static \\
\hline $\mathrm{B}_{\mathrm{s}}$ & ------- & ------ & ---- & ------ & Repeated \\
\hline $\mathrm{B}_{\mathrm{r}}$ & -------- & ------ & ------ & With & Repeated \\
\hline $\mathrm{BRC}_{1}$ & 1 & 40 & 30 & With & Repeated \\
\hline $\mathrm{BRC}_{2}$ & 1.5 & 40 & 30 & With & Repeated \\
\hline $\mathrm{BRC}_{3}$ & 2 & 40 & 30 & With & Repeated \\
\hline $\mathrm{BRD}_{1}$ & 1.5 & 30 & 30 & Without & Repeated \\
\hline $\mathrm{BRD}_{2}$ & 1.5 & 40 & 30 & With & Repeated \\
\hline $\mathrm{BRD}_{3}$ & 1.5 & 50 & 30 & \\
\hline \hline
\end{tabular}

\subsection{Materials}

The beams were cast with a concrete having a 28 day compressive strength of 27.5 $\mathrm{N} / \mathrm{mm}^{2}$ and the constituent materials for $1 \mathrm{~m}^{3}$ are given in Table.2. A normal concrete resistance was chosen in order to simulate the real case of existing beam and to better highlight the repairing effectiveness. Ordinary Portland cement and local natural sand were used. The coarse aggregate was gravel with a maximum nominal size of $20 \mathrm{~mm}$. All used materials are match with ECP 203 [6] limits. 
Table 2: Constitute materials for $1 \mathrm{~m}^{3}$ of the used concrete.

\begin{tabular}{||c|c|c|c|c|c|c|c||}
\hline $\begin{array}{c}\text { Type of } \\
\text { Concrete }\end{array}$ & $\begin{array}{c}\text { Cement } \\
\mathrm{kg} / \mathrm{m}^{3}\end{array}$ & $\begin{array}{c}\text { Silica } \\
\text { Fume } \\
\mathrm{Kg} / \mathrm{m}^{3}\end{array}$ & $\begin{array}{c}\text { Sand } \\
\mathrm{kg} / \mathrm{m}^{3}\end{array}$ & $\begin{array}{c}\text { Gravel } \\
\mathrm{kg} / \mathrm{m}^{3}\end{array}$ & $\begin{array}{c}\text { Crushed } \\
\text { Basalt } \\
\mathrm{kg} / \mathrm{m}^{3}\end{array}$ & $\begin{array}{c}\text { Additive } \\
\text { Litre/m }\end{array}$ & $\begin{array}{c}\text { Water } \\
\text { Litre } / \mathrm{m}^{3}\end{array}$ \\
\hline $\begin{array}{c}\text { Normal } \\
\text { Strength } \\
\text { Concrete }\end{array}$ & 375 & 659 & 1076 & - & & 201 \\
\hline $\begin{array}{c}\text { High } \\
\text { Strength } \\
\text { Concrete }\end{array}$ & 500 & 120 & 450 & - & 1200 & 20 & 132 \\
\hline
\end{tabular}

The repairing materials used in casting the jacket was high strength concrete of cubic strength ranged from 82.5 to $93 \mathrm{~N} / \mathrm{mm}^{2}$ after 28 days and the constitute materials for $1 \mathrm{~m}^{3}$ are given in Table. 2. Ordinary Portland cement and local natural sand were used. The coarse aggregate was crushed basalt with a maximum nominal size of 10 $\mathrm{mm}$. To enhance the strength of concrete, silica fume was used. The workability of the mix was improved by using a high - range water reduction admixture under a commercial name of Sekament R 2004.

The concrete mixes incorporated two different shapes of steel fibers, corrugated and end -hooked steel fibers of size $0.6 \times 2.0 \times 30 \mathrm{~mm}$ in ratio $1: 1$ by weight and have a minimum tensile strength of $400 \mathrm{~N} / \mathrm{mm}^{2}$.

The tension reinforcement used was made of $16 \mathrm{~mm}$ deformed bars of $430 \mathrm{~N} / \mathrm{mm}^{2}$ yield strength. Deformed bars of $10 \mathrm{~mm}$ diameter and $420 \mathrm{~N} / \mathrm{mm}^{2}$ yield strength were used as compression reinforcement. The stirrups used were made of $8 \mathrm{~mm}$ smooth bars of $310 \mathrm{~N} / \mathrm{mm}^{2}$ yield strength. The used shear connectors were high tensile steel rivets of $520 \mathrm{~N} / \mathrm{mm}^{2}$ yield strength have L shape of 50, $20 \mathrm{~mm}$ sides and $4 \mathrm{~mm}$ diameter and have end screw with a length $25 \mathrm{~mm}$.

\subsection{Repairing Technique}

The external repairing system (MSFCJ) was performed as follows:

1. Preparations of concrete surface by grinding disk then loose particles and dust have been removed by vacuum cleaner.

2. The bores to accommodate the shear connectors were drilled by using electrical drill.

3. Cleaning the bores by vacuum cleaner in order to have a good bond between the epoxy and the concrete surface then epoxy resin was placed in the bores. After that, the shear connectors were inserted into the bores at the indicated position. The embedded length of shear connectors in concrete was $28 \mathrm{~mm}$ and the free length outside the concrete surface was $22 \mathrm{~mm}$.

4. Just before cast the jacket, the epoxy adhesive was mixed and applied to the concrete surface to nominal thickness of about $0.5 \mathrm{~mm}$.

5. Cast the MSFC jacket as mentioned before.

The installation process is given in Fig.3. 

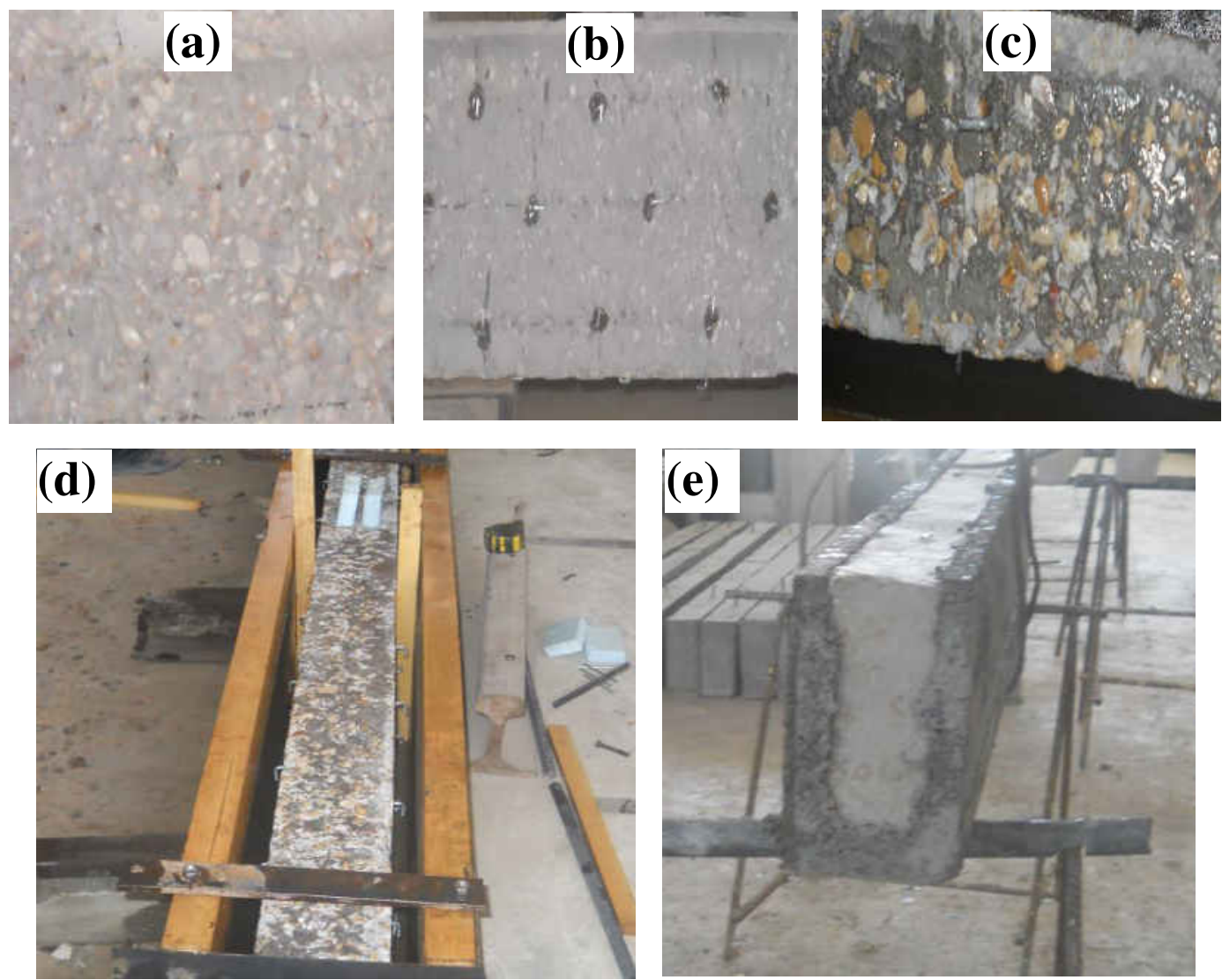

Fig.3: Repairing Technique: (a) Exposed Aggregate after Grinding Disk of Concrete; (b) Shear Connectors after Inserting into their Bores; (c) Priming Surface Process; (d) Cast the Jacket; (e) the beam after cast the jacket.

\subsection{Test Procedures and Instrumentations}

The static and repeated loading of the tested beam were made using testing machine EMS 60 tons. All beams were tested as simple beams with a clear span of $2160 \mathrm{~mm}$ using a three point loading system as shown in Fig.1.In static tests; the load was applied in increments of $5 \mathrm{KN}$. In repeated tests, the fatigue loading was applied as stationary pulsating concentrated load at the mid-span of the beam. The applied minimum load was constant at $14 \mathrm{KN}$ (weight of steel tar of testing machine). The maximum load level was taken 0.95 of the ultimate load of the reference beam tested statically $\left(\mathrm{BO}_{\mathrm{s}}\right)$. The frequency was chosen to be 500 cycles per minute and the chosen stroke was $0.5 \mathrm{~mm}$, the loading scheme is shown in Fig.4. For all the tested beams, the mid-span deflection, strain at the center of the main reinforcement, strain in the compression zone of concrete surface at mid span section, the first crack load, and the failure load were measured. The Crack patterns and failure mode were observed carefully. 


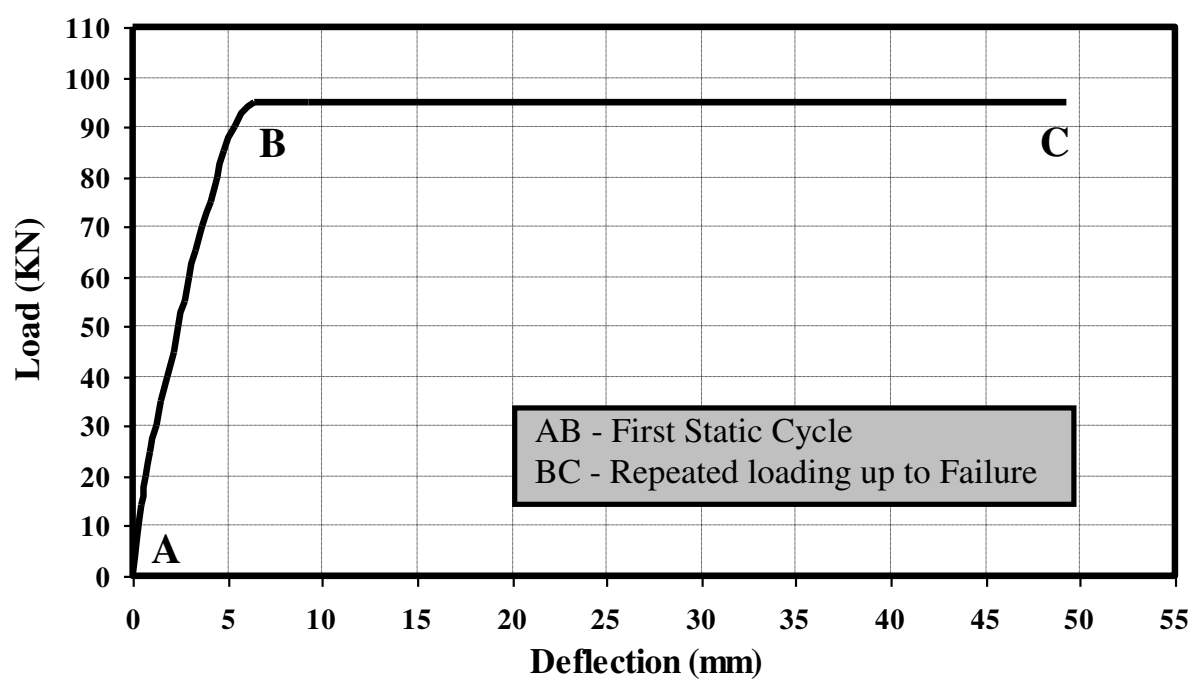

Fig. 4: Sketch of Sequence of Loading versus Deflection (Repeated Tests)

\section{TEST RESULTS AND DISCUSSIONS}

\subsection{Pattern of Crack and Mode of Failure}

For beam B0s which subjected to static loading, the first crack was observed under the point of load application at section of maximum bending moment. With further increase in the applied load, further flexural cracks are appeared and extended vertically upwards with the development of new cracks between the earlier cracks. At the last stages of loading, the cracks in the mid span zone continue to propagate vertically and few cracks developed in between, while more cracks form in the shear span, then trended to progress towards the load point diagonally (flexural-shear cracks) finally the beam failed by widening in the flexural cracks accompanied by crushing of the concrete at the top compression side under the point of load application. For "B0" which tested under repeated load, the cracks are propagated in the same manner of beam $\mathrm{B} 0_{\mathrm{s}}$ up to the end of the static loading. When the beam is subjected to the repeated loading the number and width of the cracks are increased clearly. The mode of failure as the same as "B0" more extensive.

For the repaired beams, it was clearly shown that the repairing with MSFCJ decreased the number of cracks and the cracks concentrated in the middle third of the tested beams in comparison the reference beam $\mathrm{B}_{\mathrm{r}}$. With the increasing of the steel fiber content, more cracks with smaller width was observed. This was because the steel fibers across cracks contributed in increasing the ductility of the tested beams and reducing the stress in the tensile steel reinforcement. All modes of failure for the repaired beams were flexural accompanied by crushing of the concrete at the top compression side under the point of load application except $\mathrm{BRD}_{2}$ suffered from the debonding of the jacket at the last stage of loading. This was because of the absence of shear connectors. Fig.5 shows the cracking pattern and mode of failure for all the tested beams. 

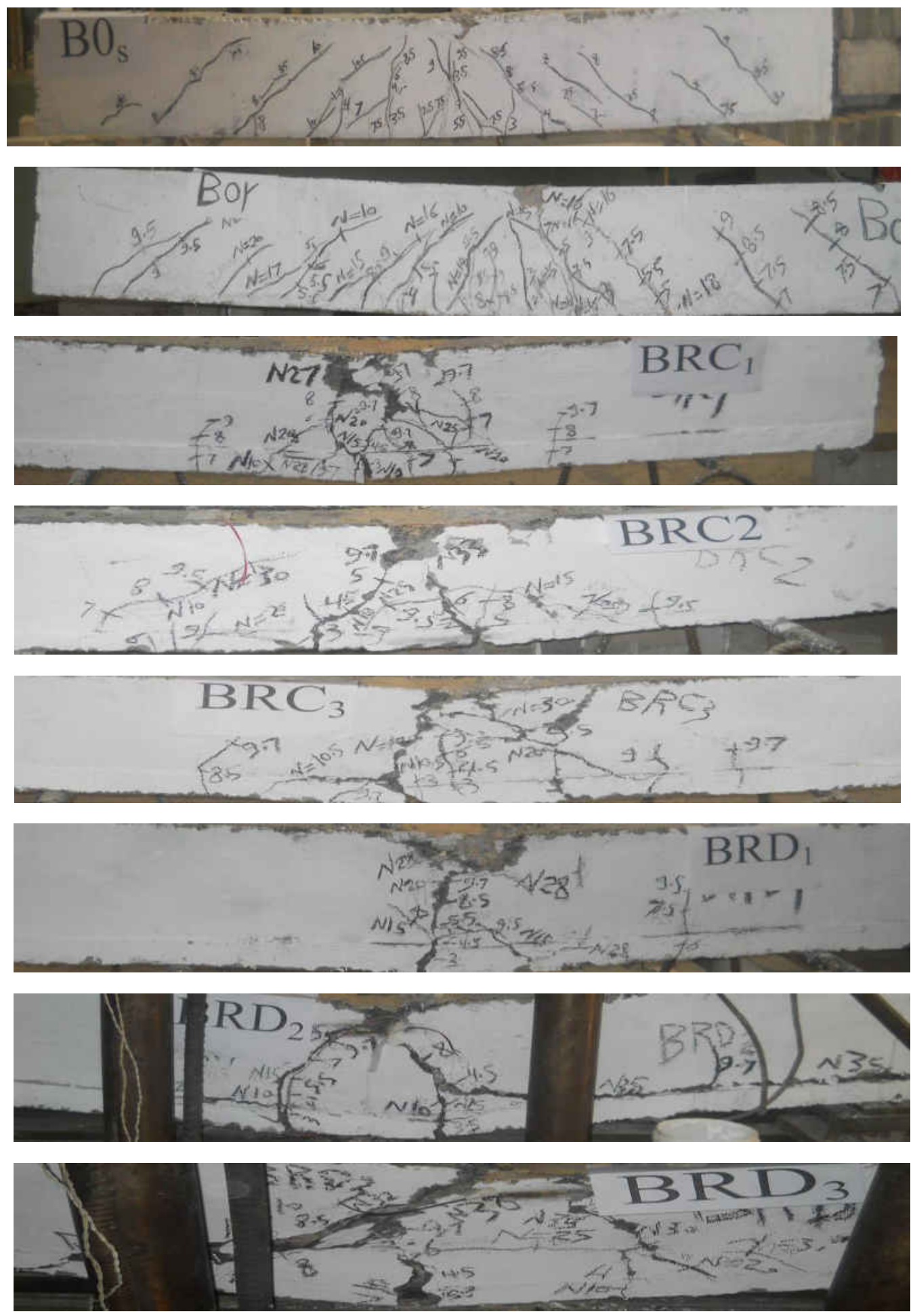

Fig. 5: Crack pattern and mode of failure of the tested beams 


\subsection{Cracking Load and Number of Cycles}

The experimental cracking loads and the maximum number of cycles for all the tested beams are presented in Table.3. The following observations can be made from the results given in this table:

- Generally, the cracking load and the number of cycles for the repaired beams are greater than the reference beam; the rate and value of increasing depend on the fiber content, thickness of the jacket and the interface strength.

- For group "C" with a constant jacket thickness and variable steel fiber content, it is clearly shown from Fig.6 and Fig.7 that the increase in steel fiber content has a slightly effect in increasing the cracking load and significantly effect in increasing the number of cycles. The increasing of steel fiber content from $1 \%$ to $1.5 \%$ increased the cracking load and the number of cycles by $17 \%$ and $88 \%$ respectively. Meanwhile, the increasing of steel fiber content from $1 \%$ to $2 \%$ increased the cracking load and number of cycles by $30 \%$ and $125 \%$ respectively. It is also clear that adding $1.5 \%$ fiber content to the concrete used in jacket has a significant effect in increasing the number of cycles. This content may be the best fiber content that can be added.

Table 3: Results of tested beams

\begin{tabular}{|c|c|c|c|c|c|c|c|c|c|c|c|c|}
\hline \multirow{2}{*}{$\begin{array}{c}\text { Beam } \\
\text { No }\end{array}$} & \multirow{2}{*}{$V_{f} \%$} & \multirow{2}{*}{$\begin{array}{c}\mathbf{t}_{\mathbf{j b}} \\
\mathbf{m m}\end{array}$} & \multicolumn{3}{|c|}{$\begin{array}{l}\text { Concrete Strengths } \\
\text { for the Jacket }\end{array}$} & \multirow{2}{*}{$\begin{array}{l}\mathbf{P}_{\text {cr }} \\
\mathrm{KN}\end{array}$} & \multicolumn{4}{|c|}{ Deformations } & \multirow{2}{*}{$\mathbf{N}$} & \multirow{2}{*}{$\begin{array}{l}\text { Mode } \\
\text { of } \\
\text { failure }\end{array}$} \\
\hline & & & $\begin{array}{c}\mathbf{f}_{\mathrm{cu}} \\
\mathrm{N} / \mathbf{m m}^{2}\end{array}$ & $\begin{array}{c}\mathbf{f c}_{\mathrm{t}} \\
\mathrm{N} / \mathbf{m m}^{2}\end{array}$ & $\begin{array}{c}\text { fer } \\
\mathrm{N} / \mathrm{mm}^{2}\end{array}$ & & $\begin{array}{c}\delta_{\text {cr }} \\
\mathbf{m m}\end{array}$ & $\begin{array}{c}\boldsymbol{\delta}_{\mathbf{u}} \\
\mathbf{m m}\end{array}$ & $\begin{array}{c}\varepsilon_{\mathrm{su}} \\
\text { micro- } \\
\text { strain }\end{array}$ & $\begin{array}{c}\varepsilon_{\mathrm{cu}} \\
\text { micro- } \\
\text { strain }\end{array}$ & & \\
\hline $\mathbf{B} \mathbf{0}_{\mathrm{s}}$ & 0 & 0 & ----- & ----- & ----- & 20 & 2.1 & 41 & 2330 & 195 & ----- & F.C* \\
\hline $\mathbf{B O}_{\mathrm{r}}$ & 0 & 0 & ----- & ----- & ----- & 20 & 2.36 & 45 & 2450 & 226 & 2500 & F.C \\
\hline $\mathrm{BRC}_{1}$ & 1 & 40 & 82.5 & 5.6 & 7.5 & 23 & 1.47 & 57.1 & 2009 & 291 & 4000 & F.C \\
\hline $\mathrm{BRC}_{2}$ & 1.5 & 40 & 90 & 7.6 & 10.9 & 27 & 1.76 & 48.4 & 1900 & 295 & 7500 & F.C \\
\hline $\mathrm{BRC}_{3}$ & 2 & 40 & 93 & 8.0 & 11.5 & 30 & 1.25 & 51.14 & 1495 & 320 & 9000 & F.C \\
\hline BRD $_{1}$ & 1.5 & 30 & 90 & 7.6 & 10.9 & 25 & 1.83 & 46 & 2200 & 360 & 4500 & F.C \\
\hline $\mathrm{BRD}_{2}$ & 1.5 & 40 & 90 & 7.6 & 10.9 & 27 & 1.44 & 62 & 2442 & 250 & 6000 & F.B $* *$ \\
\hline $\mathrm{BRD}_{3}$ & 1.5 & 50 & 90 & 7.6 & 10.9 & 33 & 1.39 & 65 & 2129 & 360 & 10000 & F.C \\
\hline
\end{tabular}

* F.C = flexural compression failure $* * \mathrm{~F} . \mathrm{B}=$ flexural bonding failure 
- For group "D" with a constant steel fiber content and variable jacket thickness, it is clearly shown from Fig.8 and Fig.9 that the increase in jacket thickness has a slightly effect in increasing the cracking load and significantly effect in increasing the number of cycles. The increasing of jacket thickness from $30 \mathrm{~mm}$ to $40 \mathrm{~mm}$ increased the cracking load and number of cycles by $8 \%$ and $34 \%$ respectively. Meanwhile, the increasing of jacket thickness from $30 \mathrm{~mm}$ to $50 \mathrm{~mm}$ increased the cracking load and number of cycles by $32 \%$ and $122 \%$ respectively.

- The absence of the shear connectors decreased the number of cycles. The number of cycles for beam $\mathrm{BRC}_{2}$ with shear connectors is larger than the identical beam $\mathrm{BRD}_{2}$ but without shear connectors by $25 \%$.

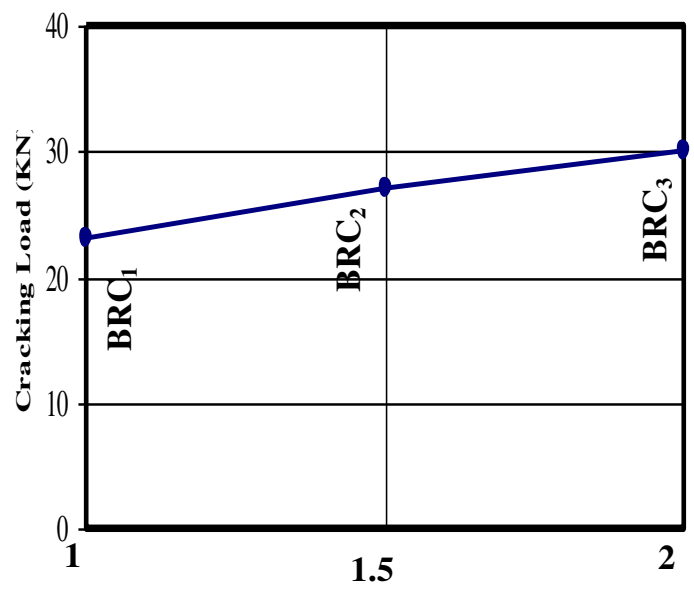

Fiber Content \%

Fig. 6: Effect of steel fiber content on cracking load of repaired

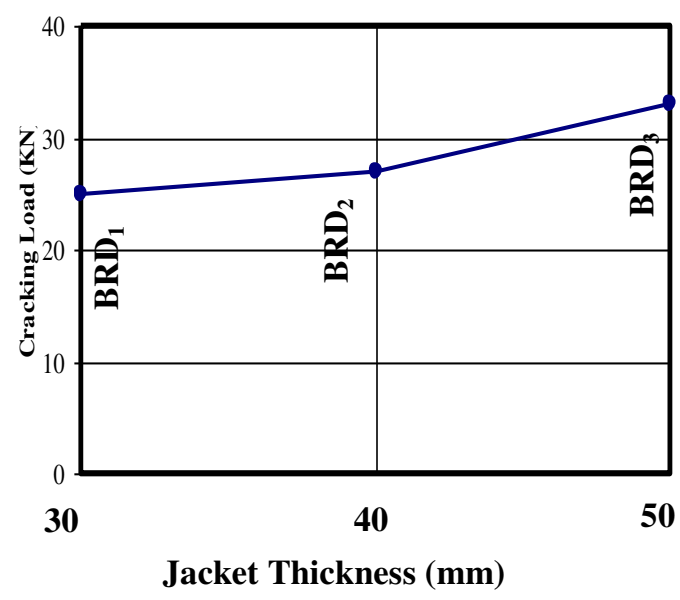

Fig.8: Effect of jacket thickness on cracking load of repaired beams.

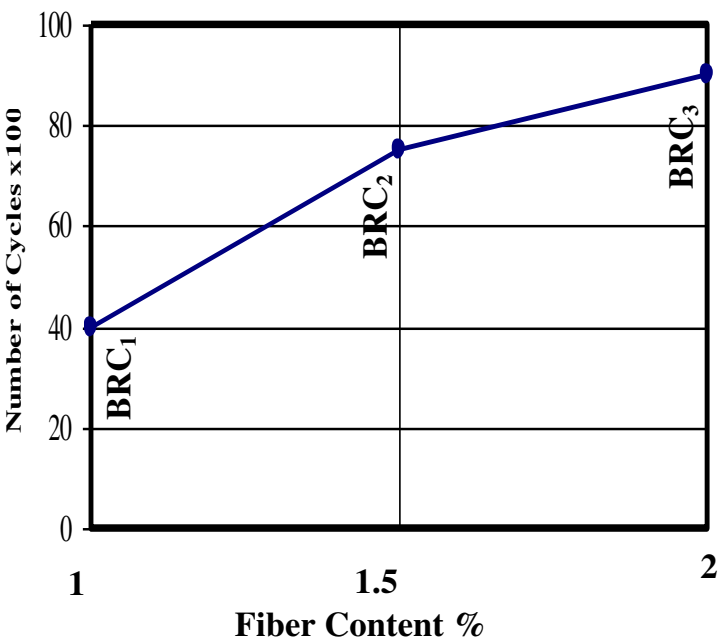

Fig. 7: Effect of steel fiber content on maximum number of cycles of repaired beams.

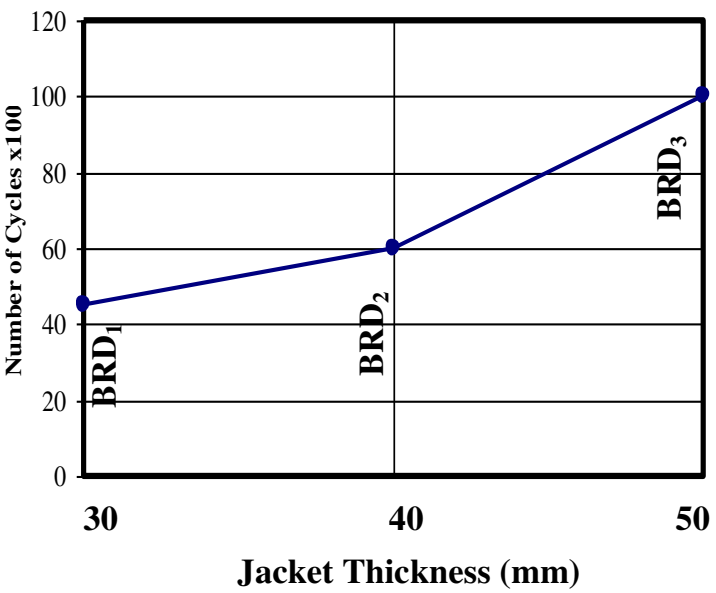

Fig.9: Effect of jacket thickness on maximum number of cycles of repaired beams. 


\subsection{Deformations}

\subsubsection{Deflection}

The relation between mid-span deflection and the number of cycles for all the beams tested under fatigue loading are shown in Fig.10 and Fig.11. The following observations can be depicted from these figures:

- It can be seen in all beams that there is an initial increase of the mid-span deflection, followed by a stable region where the deflection remained relatively constant through many cycles, followed by an abrupt increase of deflection just before failure.

- There is a more gradual increase in the deflections as the beam approaches its fatigue life. This was because the greater number of cracks resulting from the increased cycling.

- For group "C" with a constant jacket thickness and variable steel fiber content, it is clearly shown that at the same number of cycles, the mid-span deflection decreases as the fiber content increases. Increasing the steel fiber content from $1 \%$ to $1.5 \%$ decreased the mid-span deflection by $41 \%$ at 4000 cycle. Meanwhile at the same number of cycles, the increasing of steel fiber content from $1 \%$ to $2 \%$ decreases the mid-span deflection by $63 \%$ as shown in Fig. 12.

- For group "D" with a constant steel fiber content and variable jacket thickness, at the same number of cycles, the mid-span deflection decreases as the jacket thickness increases. Increasing the jacket thickness from $30 \mathrm{~mm}$ to $40 \mathrm{~mm}$ decreased the mid-span deflection by $18 \%$ at 4500 cycle. Meanwhile at the same number of cycles, the increasing of jacket thickness from $30 \mathrm{~mm}$ to $50 \mathrm{~mm}$ decreases the mid-span deflection by $39 \%$ as shown in Fig. 13.

- The absences of the shear connectors decreased the effectiveness of the repaired beam. For example at 6000 cycle the mid-span deflection for beam $\mathrm{BRC}_{2}$ with shear connectors is smaller by $43 \%$ than the identical beam $\mathrm{BRD}_{2}$ but without shear connectors.

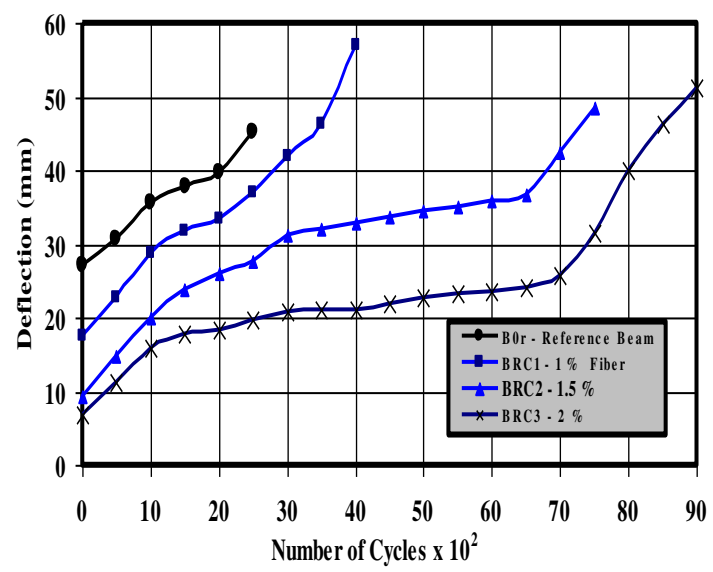

Fig.10: Effect of steel fiber content on variation of mid span deflection with number of cycles for repaired beams.

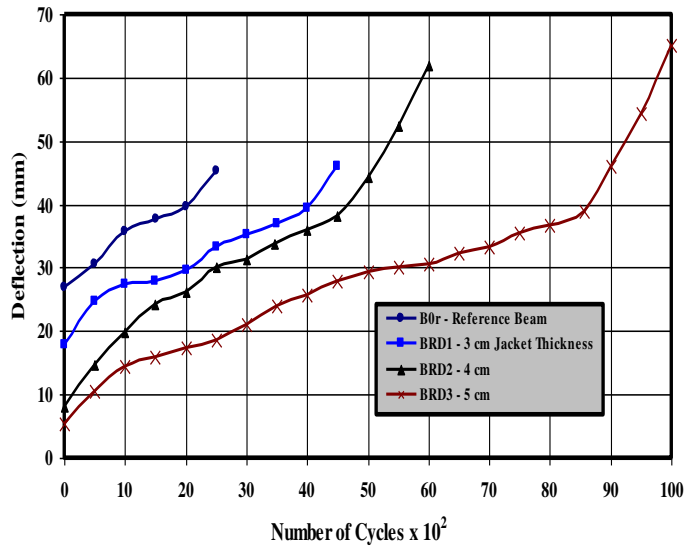

Fig.11: Effect of jacket thickness on variation of mid span deflection with number of cycles for repaired beams. 


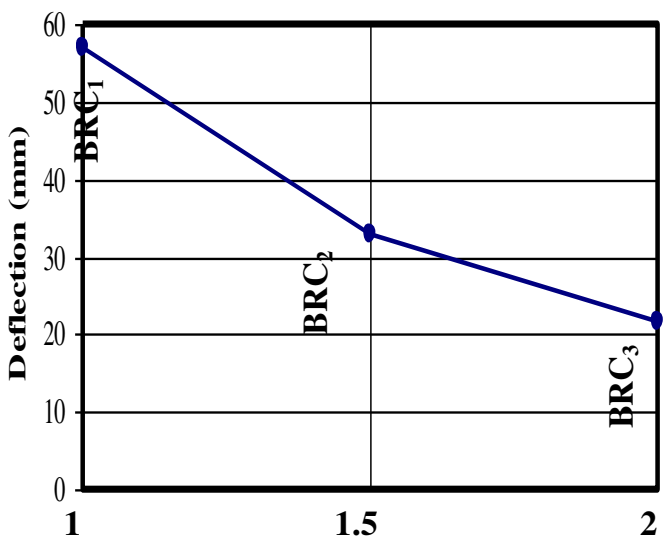

Fiber Content \%

Fig.12: Effect of steel fiber content on mid-span deflection of repaired beams after 4000 cycles.

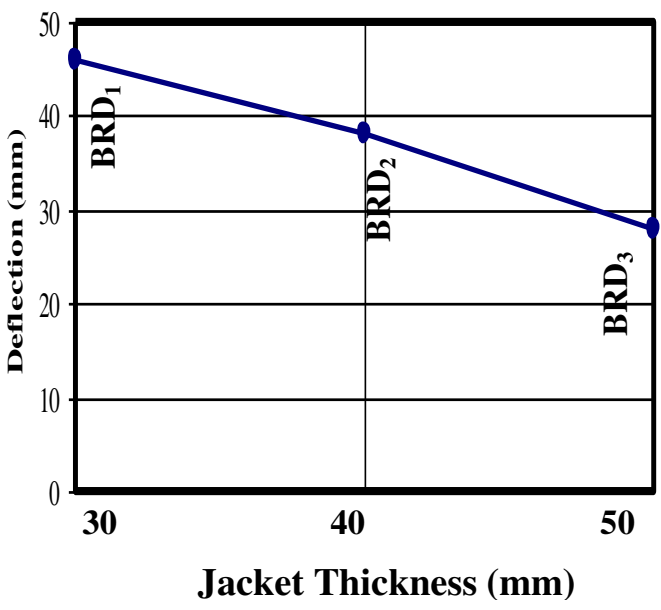

Fig. 13: Effect of jacket thickness on mid-span deflection of repaired beams after 4500 cvcles

\subsubsection{Strains}

The recorded strains on the steel reinforcement and concrete at top surface for the tested beams are shown in Fig.14 to Fig.17. The following observations can be disclosed from these figures:

- The strain in the reinforced steel increased suddenly before failure, indicating yielding of the reinforcement. At that point, strain in the concrete increased but remained lower than strains corresponding to expected ultimate behavior, 0.003 .

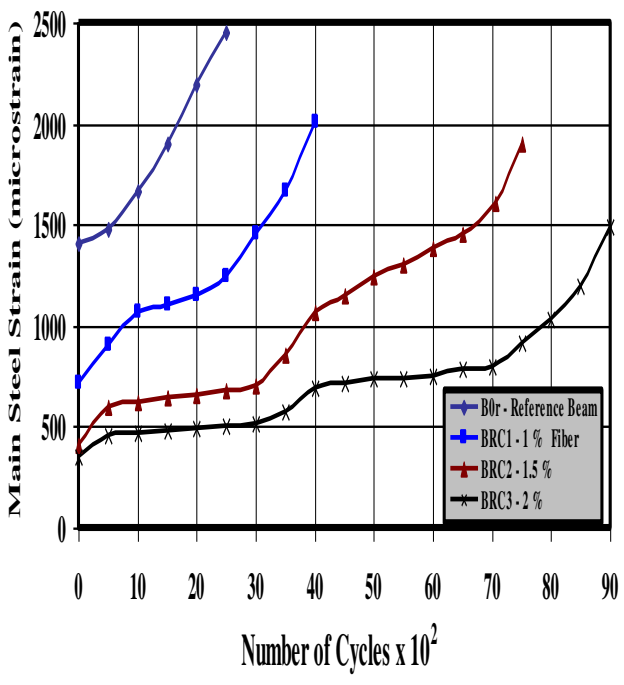

Fig. 14: Effect of steel fiber content on variation of main steel strain with number of cycles for repaired beams.

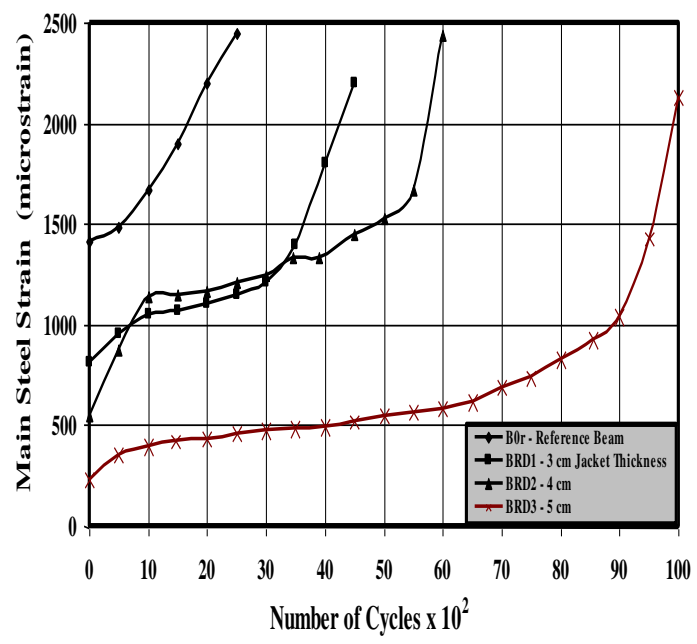

Fig. 15: Effect of jacket thickness on variation of main steel strain with number of cycles for repaired beams. 


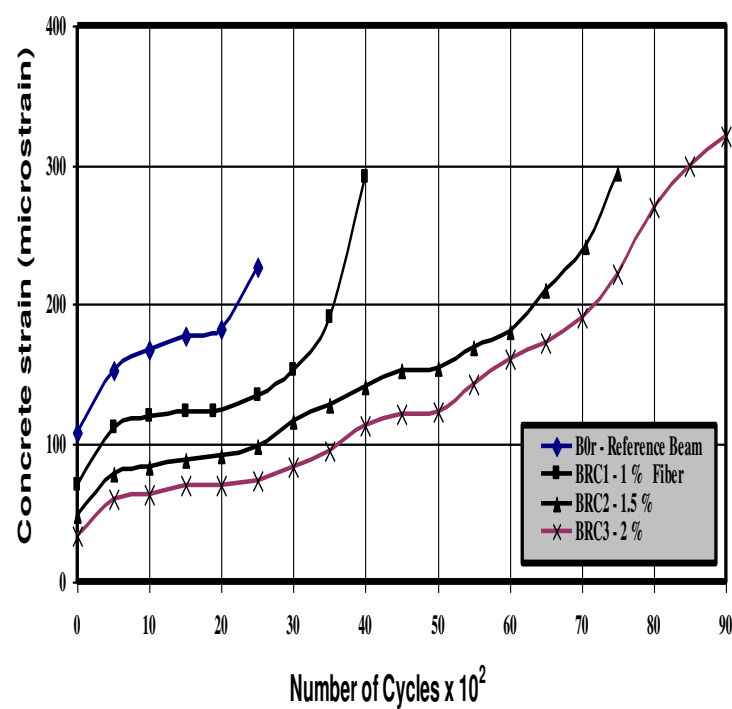

Fig.16: Effect of steel fiber content on variation of concrete strain with number of cycles for repaired beams.

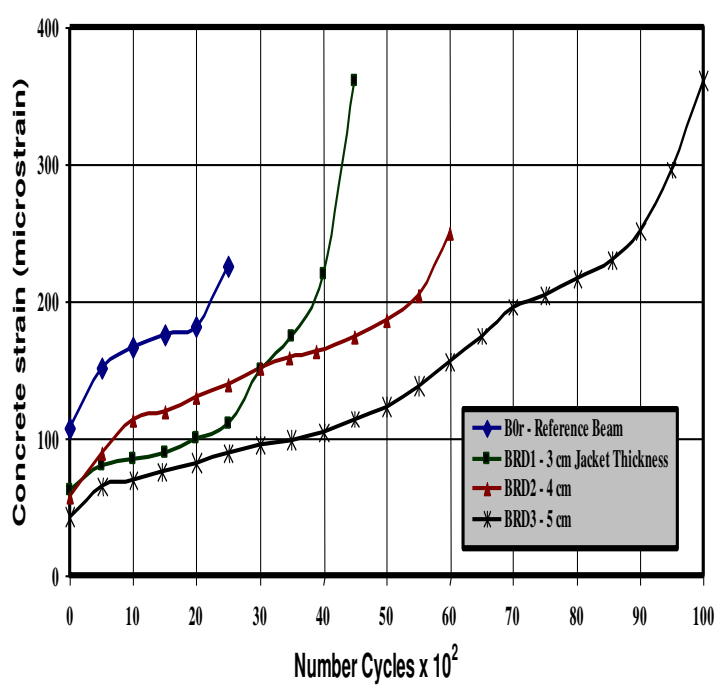

Fig. 17: Effect of jacket thickness on variation of concrete strain with number of cycles for repaired beams.

- There is a more gradual increase in the steel and the concrete strain as the beam approaches its fatigue life. This may be due to increasing the deflection resulting from the increased cycling.

- For group "C" with a constant jacket thickness and variable steel fiber content, at the same number of cycles, the strains decrease as the fiber content increases. Increasing the steel fiber content from $1 \%$ to $1.5 \%$ decreased the main steel strain and concrete strain by $47 \%$ and $55 \%$ respectively at 4000 cycle. Meanwhile at the same number of cycles, the increase of steel fiber content from $1 \%$ to $2 \%$ decreases the main steel strain and concrete strain by $65 \%$ and $64 \%$ respectively as shown in Fig. 18 and Fig. 19.

- For group "D" with a constant steel fiber content and variable jacket thickness, at the same number of cycles, the strains decrease as the jacket thickness increases. Increasing the jacket thickness from $30 \mathrm{~mm}$ to $40 \mathrm{~mm}$ decreases the main steel strain and concrete strain by $34 \%$ and $51 \%$ respectively at 4500 cycle. Meanwhile at the same number of cycles, the increasing of jacket thickness from $30 \mathrm{~mm}$ to $50 \mathrm{~mm}$ the main steel strain and concrete strain decrease by $78 \%$ and 69\% respectively as shown in Fig. 20 and Fig. 21.

- The absences of the shear connectors increased the strains for the repaired beams. For example at 6000 cycle, the main steel strain and concrete strain for beam $\mathrm{BRC}_{2}$ with shear connectors is smaller than the identical beam $\mathrm{BRD}_{2}$ but without shear connectors by $40 \%$ and $26 \%$ respectively. 


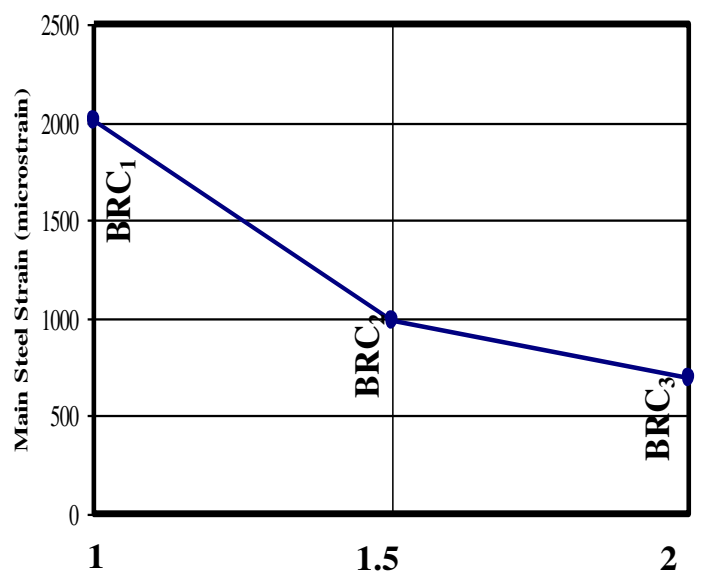

Fiber Content \%

Fig. 18: Effect of steel fiber content on main steel strain of repaired beams after 4000 cycles.

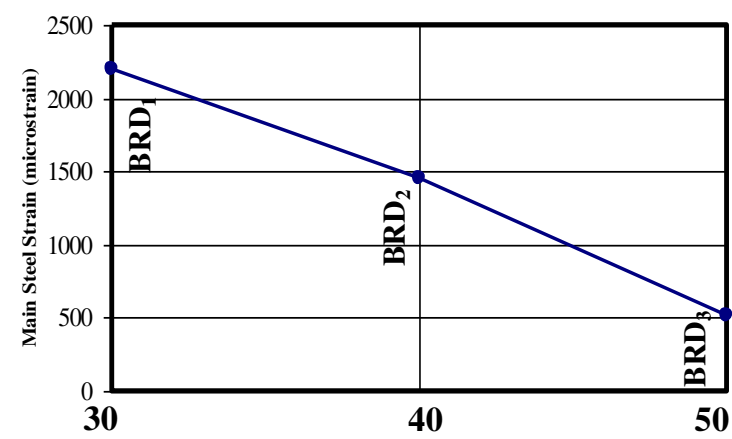

Jacket Thickness (mm)

Fig. 20: Effect of jacket thickness on main steel strain of repaired beams after 4500 cycles.

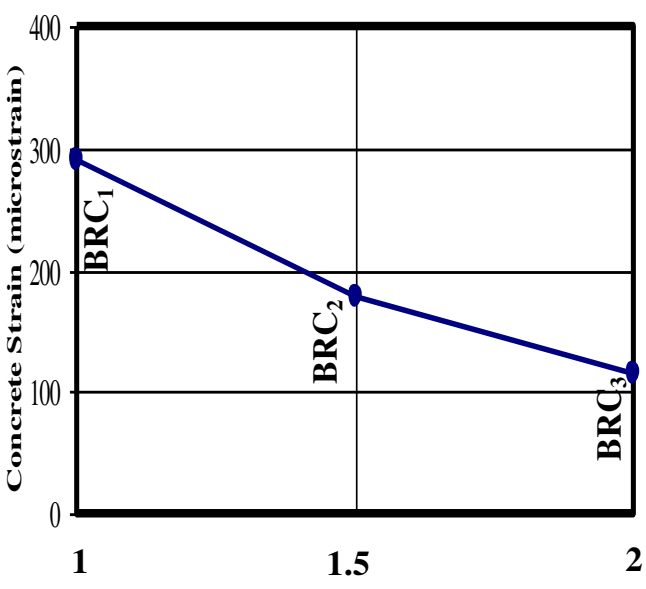

Fiber Content \%

Fig. 19: Effect of steel fiber content on concrete strain of repaired beams after 4000 cycles.

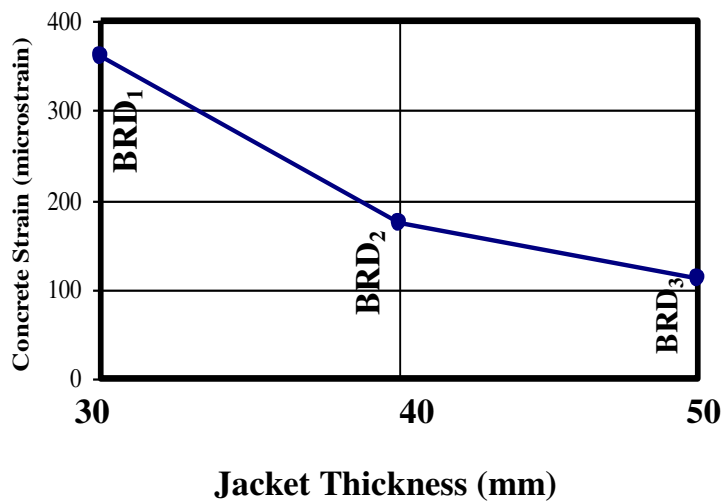

Fig. 21: Effect of jacket thickness on concrete strain of repaired beams after 4500 cycles.

\section{CONCLUSIONS}

Based on the test results and discussions above, the following conclusions can be drawn:

1. The repairing with MSFC jacket decreases the number of cracks and they were concentrated in the middle third avoiding the forming of shear cracks.

2. Presences of shear connectors in the jacket play a role in enhancing the bonding between the main beam and the jacket and prevent the debonding failure. While, the absence of shear connectors leads to prevent the repaired beams to reach its predicted maximum number of cycles. 
3. The application of MSFC jacket on a $\mathrm{RC}$ beam provides a significant increase in the repaired beams stiffness.

4. The application of MSFC jacket with $40 \mathrm{~mm}$ jacket thickness at bottom surface, $30 \mathrm{~mm}$ at each side and variable fiber content $1 \%, 1.5 \%$ and $2 \%$ on the cracked beams provides an increase of the maximum number of cycles by $60 \%, 200 \%$ and $260 \%$ respectively with respect to the reference beam.

5. The application of MSFC jacket with $1.5 \%$ fiber content, $30 \mathrm{~mm}$ thickness at each side and variable thickness at tension surface $30 \mathrm{~mm}, 40 \mathrm{~mm}$ and $50 \mathrm{~mm}$ on the cracked beams provides an increase of the maximum number of cycles by $80 \%, 140 \%$ and $300 \%$ respectively with respect to the reference beam.

6. Adding $1.5 \%$ fiber content to the concrete used in the jacket has a significant effect in increasing the number of cycles and decreasing both the deflections and strains. This content may be the ideal fiber content.

\section{REFERENCES}

1. Fatih Altun, "An Experimental Study of the Jacketed Reinforced Concrete Beams under Bending", Construction and Building Materials, Vol.18, PP.611618.June 2004.

2. Giovanni Martinola, Alberto Meda, Giovanni A. Plizzari and Zila Rinaldi, "Strengthening and Repairing of RC Beams with Fiber Reinforced Concrete", Cement، Concrete Composites, Vol.32, PP.731-739, July 2010.

3. Byung Hwan, "Flexural Analysis of Reinforced Concrete Beams Containing Steel Fibers", Journal of Structural Engineering, Vol.118, No.10, PP.151-742, October 1992.

4. Johnston, C.D., Zemp, R.W., "Flexural Fatigue Performance of Steel Fiber Reinforced Concrete Influence of Fiber Content, Aspect Ratio and Type", ACI Materials Journal, Vol.88. No.4, PP.374-383, 1991.

5. Nasser Abdel Salam, "Repair and Strengthening of Reinforced Concrete Beams Using Fiber Reinforced Concrete", M.Sc. Thesis, Zagazig university, Egypt, 2005.

6. Egyptian Code of Practice For Design and Construction of Concrete Structures ECCS 203-2007

7. ACI Committee 215 "Consideration for Design of Concrete Structures Subjected to Fatigue Loading", ACI Journal, V.71, PP. 97-121, No.3, 1974.

8. Regina Helena F. Souza and Julio Appleton, "Flexural Behavior of Strengthened Reinforced concrete beams", Materials and Structures, Vol.30, PP.154-159, April 1997.

9. Sayed, M.S., "Flexural Behavior of Cracked R.C Beams Strengthened Using Steel and/or Polypropylene Fibers Concrete", M.Sc. Thesis, Cairo university, Egypt, 1999.

10. Y. G. Diab, "Strengthening of RC Beams by Using Sprayed Concrete", Engineering Structures, Vol.20, No.7, PP.631-643, January 1997.

11. Zhang Jun and Henrik Stang, "Fatigue performance in Flexure of Fiber Reinforced Concrete", ACI Structural Journal, Vol.95, No.1, PP.58-67, January 1998. 


\section{سلوك الكمرات الخرسانية المسلحة المعالجة بقميص من الخرسانة ذات}

\section{الألياف والمعرضة لتحميل متكرر قصير الفترة}

إن إعادة إصلاح الكمرات الذرسانية المسلحة بأستخدام قميص من الذرسانة المدعمة بالألياف يتسم بالعديد

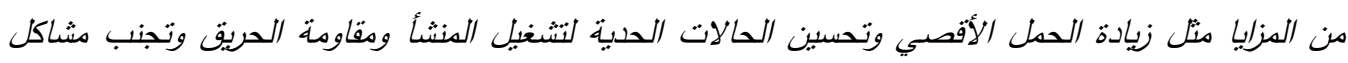

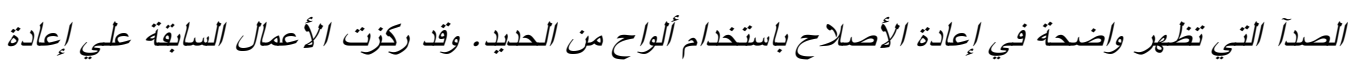

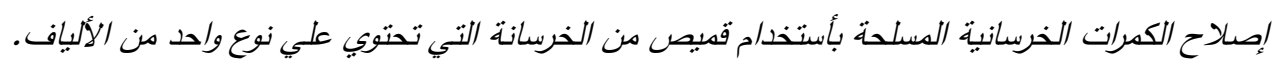

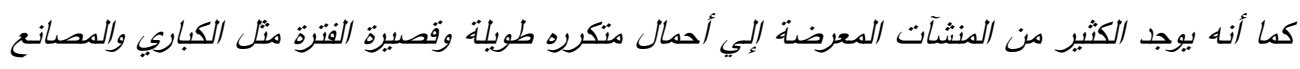

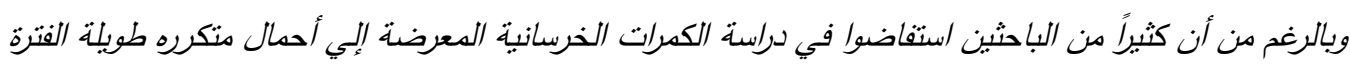

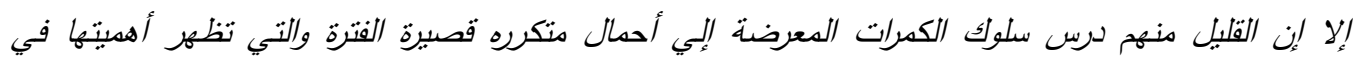

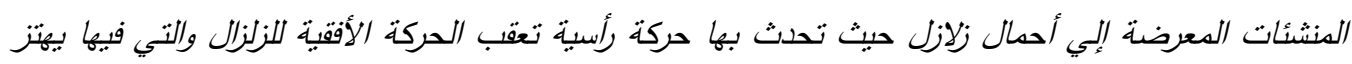
المنثأ رأسياً بكامل طاقته. ومن ثم كان الهذف من هذا البحث إستذدام الخرسانة الدعمة بذليط من الألماف في إعادة إصلاح الكمرات

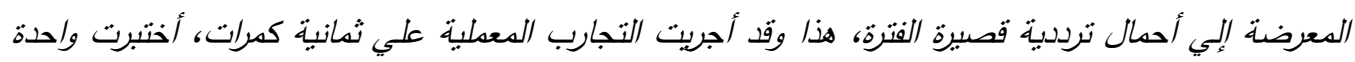

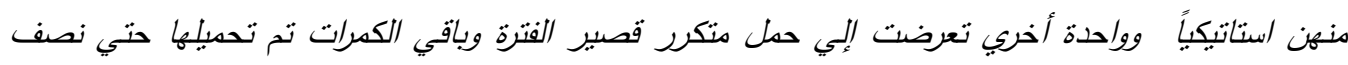

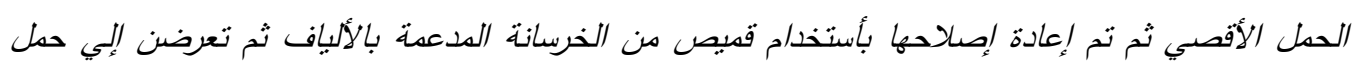

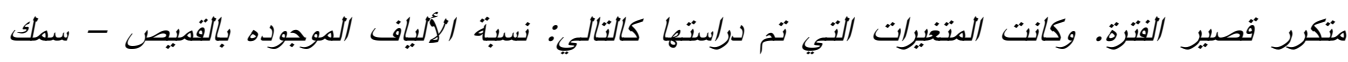
القميص - طريقة أتصال القميص مع الكمرات الأصلية.

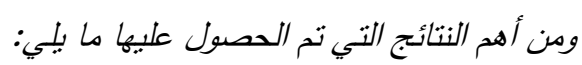

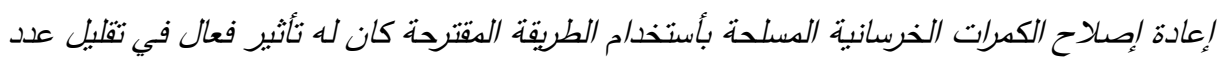

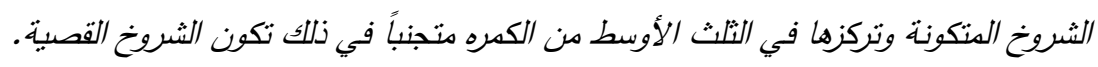

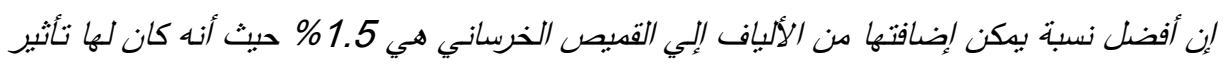

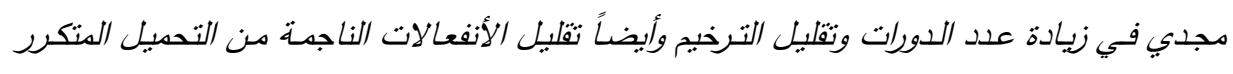
قصبير الفترة. وجد أن زيادة سدك القمبص له تأثير فعال أيضاً في زيادة عدد الدورات وتقلبل الهبوط والأنفعالات الناجمة من التحميل المتكرر قصبي الفترة.

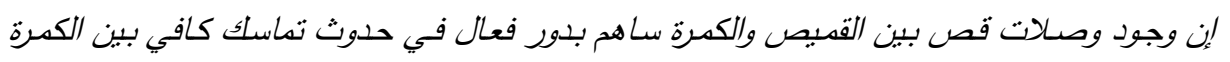
والقميص الخرساني متجنباً في ذلك حدوث إنفصال للقميص عن الكمرة. 